\title{
PREEMPTION OF STATE LAW BY THE FEDERAL TRADE COMMISSION
}

\author{
PaUl R. VerkUIL*
}

The Federal Trade Commission is currently embarked on a regulatory program that could render the combined effect of all of its prior activity insignficant by comparison. Through the use of recently activated trade regulation rule power the Commission is boldly reaching out to preempt state laws and regulations that inhibit, in a variety of ways. the operation of the competitive market. Already under attack are restrictions on prescription drug price advertising by pharmacists and prescription eyeglass advertising by optometrists and ophthalmologists. ${ }^{1}$ Soon to come under similar scrutiny are activities by veterinarians, funeral hoines, appliance repair businesses, and real estate brokers. ${ }^{2}$ The Commission's approach is to mandate, through rules, federal deregulation of state activity that protects selected businesses and professions froin the vicissitudes of coinpetition. While estimates are difficult to inake, it does not seem unreasonable to predict that undoing the effect of these and similar regulatory programs would save the consumer several billion dollars in additional charges each year. ${ }^{3}$ Looked at from

* Associate Professor of Law, University of North Carolina. A.B. College of William \& Mary, 1961; LL.B. University of Virginia, 1967; IL.M. 1969, J.S.D. 1972, New York University; M.A. New School for Social Research, 1971. The author was a consultant to the Federal Trade Commission on the preemption issue discussed in this Article.

THE FOLIOWING CITATION WILL BE USED IN THIS ARTICLE:

Federal Trade Commission, Staff Report on Prescription Drug Price DisclosURES (1975) [hereinafter cited as STAFF REPORT].

1. See FTC News Summary, June 6, 1975, at 1, 4 (proposed prescription drug price advertising rules); id., Dec. 26, 1975, at 1 (proposed ophthalınic goods and services rule).

2. See id., Jan. 2, 1976, at 2, 3 (investigations of occupational regulation in veterinary medicine; residential real estate brokerage industry; and state-imposed barriers to entry in appliance repair industry); id., Dec. 26, 1975, at 3 (announcement of funeral industry rulemaking proceedings).

3. See, e.g., Benham, The Effect of Advertising on the Price of Eyeglasses, $15 \mathrm{~J}$. LAw \& ECON. 337 (1972) (documenting additional costs to consumers of eyeglasses in states that restrict price advertising); Stigler, The Theory of Economic Regulation, 2 BeLl J. ECoN. \& MANAGEMENT SCI. 3 (1971) (discussing eleven state-licensed occupations (including pharmacists) and concluding that licensees enjoy such profit advantages that regulation itself becomes a product governed by laws of supply and demand). 
this perspective, these deregulation programs could well exceed the total consumer benefit of all the Commission's prior regulatory activities. ${ }^{4}$

The current FTC rulemaking activity seems to be part of a general awakening to the inefficiencies inherent in government regulation of the marketplace at all levels. The Administration has commenced a inajor drive for economic reform by urging deregulation of government activities generally, ${ }^{6}$ and specifically by agencies such as the Civil Aeronautics Board and the Interstate Commerce Commission that restrict price competition by airlines and motor carriers. ${ }^{6}$ This approach appears, on the surface at least, to have been reinforced by the Supreme Court in important cases like The Great Atlantic \& Pacific Tea Co. v. Cottrell ${ }^{7}$ and Goldfarb v. Virginia State Bar, ${ }^{8}$ which utilize the commerce clause and the Sherman Act, respectively, to undo state laws and professional practices that inhibit retail price competition in the distribution of milk and price competition in the provision of lawyers' services.

But, despite this apparent affirmation, the Commission's rulemaking proceedings are causing considerable consternation in several important quarters. Many states are understandably uneasy about broad federal intervention into matters of heretofore state economic concern, and serious questions are being raised about the power of the Commission to preenpt state laws and regulations. ${ }^{9}$ This unease has been

4. A trenchant criticism of the Commission has been its failure to analyze its enforcement activities in cost-benefit terms. See generally Posner, The Federal Trade Commission, 37 U. CHr. L. Rev. 47 (1969).

5. See Address by President Ford, N.Y. Times, Oct. 9, 1974, at 24, col. 2 (advocating deregulation at federal level and antitrust attacks upon state regulation). The Justice Department has commenced several antitrust actions against professional associations, the latest one against the American Pharmaceutical Association for conspiring to restrain trade through its Code of Ethics that prohibits price advertising of prescription drugs. United States v. American Pharmaceutical Ass'n, Civil No. G 75-558-CA 5 (W.D. Mich., filed Nov. 11, 1975). The FTC has followed this lead with a section 5 complaint against the American Medical Association for its principles of Medical Ethics which prevent price advertising of medical services. See FTC NEWS SUMMARY, Dec. 26, 1975 , at 1.

6. See H.R. 10,261, 94th Cong., 1st Sess. (1975) (bill to reform CAB); H.R. 12,084, 94th Cong., 2d Sess. (1976) (Motor Carrier Reform Act).

7. 96 S. Ct. 923 (1976).

8. 421 U.S. 773 (1975); accord, United States v. Oregon State Bar, 385 F. Supp. 507 (D. Ore. 1974). The Court will rule on the first amendment implications of prescription drug advertising restrictions this term. Virginia Citizens Consumer Council v. Virginia State Bd. of Pharmacy, 373 F. Supp. 683 (E.D. Va. 1974), prob. juris. noted, 420 U.S. 971 (1975).

9. See, e.g., Letter from Anthony F. Troy, Chief Deputy Attorney General of Virginia, to William D. Dixon, Special Assistant Director for Rulemaking of the Federal Trade Commission, Aug. 5, 1975, prepared for FTC prescription drug price advertising rulemaking proceedimg. 
effectively communicated to Congress. A joint congressional resolution is currently circulating in the halls of Congress which would declare the Commission's newly minted rulemaking power to be non-preemptive. ${ }^{10}$ There seems to be little doubt that the preemption issue invites controversy even from those who are enthusiastic about the merits of the underlying economic issues.

The debate about preemption before the Commission largely centers upon Parker $v$. Brown, ${ }^{11}$ a celebrated case that refused to allow the Sherman Act to upset a state regulatory scheme limiting the production and marketing of agricultural products in California. Despite considerable confusion over the scope and meaning of what has become known as the Parker doctrine, ${ }^{12}$ the case is inevitably linked to a resolution of the preemption issue. This is because Parker is one of the few judicial attempts to reconcile the twin policies of antitrust and federalism. Even Goldfarb, which seemingly strengthens current antitrust policies, does not fail to acknowledge the continued viability of the Parker doctrine. ${ }^{13}$

Obviously inuch is at stake on both sides of the preemption debate. If the Commission is allowed to pursue its new regulatory program without serious restraint, it can virtually undo the vast network of "fence-me-in" laws that have distorted the competitive market since the 1930s. ${ }^{14}$ At the same time, however, the success of that effort could do much to anachronize cherished notions of state independence and autonomy. What is needed is a way of striking a balance between these competing values. Ideally, this requires an approach that seeks to maximize the efficiency goal while doing only minimal injury to the political goal. This Article will explore the policy debate with this ideal in mind and suggest a methodology that balances the legislative, administrative, and judicial functions accordingly.

\section{The Preemption Issue in Context}

The Commission's prescription drug price advertising rule (drug

10. One congressional resolution, H.R. Cong. Res. 483, 94th Cong., 1st Sess. (Nov. 18, 1975) resolves: "That the Congress has not delegated to the Federal Trade Commission any authority to preempt the laws of the States and their political subdivisions." For further discussion of this proposed resolution, see notes 90-91 infra and accompanying text. A resolution supporting FTC preemption has been introduced by Senator Church. S. Res. 357, 94th Cong., 2d Sess. (Jan. 27, 1976).

11. 317 U.S. 341 (1943).

12. See generally Handler, The Current Attack on the Parker v. Brown State Action Doctrine, 76 Colum. L. Rev. 1 (1976); Verkuil, State Action, Due Process and Antitrust: Reflections on Parker v. Brown, 75 ColuM. L. Rev. 328 (1975).

13. Goldfarb v. Virginia State Bar, 421 U.S. 773, 788-92 (1975).

14. See W. Gellhorn, Individul Freedom and Governmental Restraints 10551 (1956). 
rule) provides the best framework for analysis of the preemption issue because that rule is the first to raise the preemption question directly, ${ }^{15}$ in the context of articulated debate, ${ }^{16}$ and with the prospect that the rule will serve as the vehicle for judicial review. ${ }^{17}$ The drug rule declares it to be an unfair act or practice (1) for any person to hinder, restrict, or prohibit "the disclosure by any retail seller of accurate price information regarding prescription drugs;"18 and (2) for any retail seller "to fail to disclose adequate price information regarding prescription drugs to potential purchasers."19 As part of the second requirement, the rule is deemed violated if the retail seller refused to disclose "because of or in connection with any law, rule, regulation or code of conduct of any nonfederal legislative, executive, regulatory or licensing entity or any other entity or person whatsoever, including but not limited to professional associations . . . ."20 To ensure that this language is not misunderstood, the rule closes with a clear declaration of Commission intent:

It is the intent of the Commission that this part shall preempt all nonfederal laws, ordinances or regulations that are repugnant to this part, that would in any way frustrate the purpose of this part, that would in any way prevent or burden any disclosures of accurate prescription drug price information by retail sellers to potential purchasers . . . .21

If proinulgated substantially as proposed, the inpact of this rule on state laws and regulations will be staggering. Twenty-four states directly prohibit the advertising of actual prices of prescription drugs by pharmacies; twelve do so by statute and twelve by pharmacy board

15. The preemption issue was present in earlier rulemaking proceedings but it attracted little attention. The trade regulation rule which establishes a cooling-off period for door-to-door sales, promulgated October 18, 1972, provides that state laws or municipal ordinances would be preempted to the extent that they "are directly inconsistent with the provisions of this section." 16 C.F.R. $\$ 429$, Note 2(b) (1975). It should be noted that this rule was promulgated before the Commission's grant of rulenaaking power in the 1975 amendment. See note 61 infra.

16. The Commission has devoted substantial attention to the preemption issue in its report accompanying the rule, see STAFF REPORT 493-589, and several witnesses have submitted testimony on the issue. See Letter froin Anthony F. Troy, supra note 9; Statement of the Federation of Associations of Health Regulatory Boards, presented at the Federal Trade Commission's Drug Rule Hearing, Jan. 13, 1976.

17. By all indications the drug rule will be the first completed rulemaking proceeding. Judicial review of the rule may be sought within sixty days in an appropriate federal court of appeals. 15 U.S.C.A. $\$ 57$ a(e) (Supp. 1976).

18. Disclosure Regulations Concerning Retail Prices for Prescription Drugs, 40 Fed. Reg. 24,031 (1975) (codified at 16 C.F.R. $\$ 447.2$ ).

19. Id. (codified at 16 C.F.R. $\$ 447.3$ ).

20. Id.

21. Id. at 24,032 (codified at 16 C.F.R. $\$ 447.5$ ). 
regulations. ${ }^{22}$ In addition, some eleven other states inhibit the advertising practices of pharmacists in ways which would undoubtedly "frustrate the purpose" of the Commission's rules. ${ }^{23}$ Thus some thirty-five states will have explicit expressions of their public policy preempted by the drug rule when it goes into effect. While the remaining states either liave no position on the matter, or have enacted laws and policies that are in agreement with the drug rule, ${ }^{24}$ the overall effect of the rule represents a dramatic challenge to the principles of federalism.

The power to preempt derives from the supremacy clause of the Constitution, ${ }^{25}$ which invalidates any state law or regulation that "stands as an obstacle to the accomplishment and execution of the full purposes and objectives of Congress."28 Where there is either congressional intent to occupy the field of regulation or a direct conflict between federal and state law which creates a "repugnancy," preemption occurs automatically, without any inquiry into the importance of the state interest. ${ }^{27}$ Usually the search for congressional intent is only crucial when the issue is federal occupation of the field, since if there is a repugnancy situation the federal statute will in all likelihood resolve the preemption issue on its face, or clearly within its terms. When the preemption is created by federal agency rule, however, the question of congressional intent remains serious even though the rule is repugnant to state laws or regulations, as is the drug rule. In this situation the agency is acting as the legislature, or more precisely sublegislature, ${ }^{28}$ and the court must still determine whether Congress intended to give the agency the power to occupy the field or to create substantive rules repugnant to state law. The requisite congressional intent to allow agencies to preempt by rulemaking has been found on many occasions in other contexts. ${ }^{29}$ In those cases, lowever, the question was only

22. These laws have been collected and analyzed by the Commission. See STAFP REPORT 33.

23. Some states inhibit price advertising by requiring extensive medical information to accompany the advertisements and some bar the advertising of controlled substances. See id. at 33-34.

24. Five states have recently reinoved all advertising prohibitions, and several states require affirmative posting of prescription drug prices in pharmacies. See id. at 34-35.

25. U.S. CoNST. art. VI, $\S 2$.

26. Florida Lime \& Avocado Growers, Inc. v. Paul, 373 U.S. 132, 141 (1963).

27. In Free v. Bland, 369 U.S. 663 (1962), the Court stated: "The relative importance to the State of its own law is not material when there is a conflict with a valid federal law, for the Framers of our Constitution provided that the federal law inust prevail." Id. at 666 .

28. See W. Gellhorn \& C. Byse, Administrative Law 732 (6th ed. 1974).

29. See, e.g., Free v. Bland, 369 U.S. 663 (1962) (treasury regulations); Public Utilities Comm'n v. United States, 355 U.S. 534 (1958) (procurement regulations); Leslie Miller, Inc. v. Arkansas, 352 U.S. 187 (1956) (same). 
whether the rules were intended to have the force and effect of law. While this question must also be asked in the context of the drug rule, $^{30}$ additional emphasis is placed upon the task of establishing congressional intent to preempt when the federal power is asserted through the antitrust laws. This is where Parker comes in, the Court having there stated:

We find nothing in the language of the Sherman Act or in its history which suggests that its purpose was to restrain a state or its officers or agents from activities directed by its legislature. In a dual system of government in which, under the Constitution, the states are sovereign, save only as Congress may constitutionally subtract from their authority, an unexpressed purpose to nullify a state's control over its officers and agents is not lightly to be attributed to Congress.

The Sherman Act makes no mention of the state as such, and gives no lint that it was intended to restrain state action or official action directed by a state. ${ }^{31}$

This desire not lightly to attribute preemption to the Sherman Act becomes an additional hurdle for traditional preemption analysis. The reason for this mcreased concern with preemption lies in the problems confronting the Court when the case arose. ${ }^{32}$ The Court that decided Parker was in the process of energing from substantive economic review of state laws and regulations under the due process clause. If the Sherman Act had been made preemptive the effect would have been much like returning the Court to the era of substantive due process review. The Sherman Act, with its broad due process-like reacl, ${ }^{33}$ has the potential to be a surrogate substantive due process clause, limited only by the constantly shrinking interstate commerce requirement and the active imagination of the Department of Justice. ${ }^{34}$ This understand-

30. There is no serious doubt that the drug rules, whether or not they are intended to preempt, are clearly intended to have the substantive effect and force of law. See STAFF REPORT 493-507.

31. 317 U.S. $341,350-51$ (1943).

32. This historical argument is more fully developed in Verkuil, supra note 12, at $330-40$.

33. See Appalachian Coals, Inc. v. United States, 288 U.S. 344, 359-60 (1933); accord, United States v. Topco Associates, Inc., 405 U.S. 596, 610 (1972) ("Antitrust lavs in general, and the Sherman Act in particular, are the Magna Carta of free enterprise.").

34. The Justice Department's antitrust division appears to be turning with enthusiasm to the task of suggesting possible antitrust actions against state laws and regulations. For example, even Sunday closing laws have been mentioned as potential targets for antitrust actions. See Verkuil, supra note 12, at 334 n.36. The substantive due process analogy is heightened when it is recalled that Justice Holmes in his legendary Lochner dissent specifically neentioned Sunday laws and usury laws as "ancient examples" of laws 
able concern with the preemptive effect of the antitrust laws-im particular the Sherman Act-is not without parallel today in the concern about the limits on the imagination of another federal agency, the Federal Trade Commission. By asserting the power to preempt under the equally broad provisions of section 5 of the Sherman Act, the Commission is inevitably mvoking the concerns that led to the Parker decision in the first place.

There are certainly grounds for distinguishing Parker that are worthy of consideration. The Commission has asserted, ${ }^{35}$ and recent comment has supported, ${ }^{36}$ the idea that the Federal Trade Commission Act (FTCA) is not the kind of "antitrust law" that worried the Parker Court. The FTCA is seen as different from the Sherman Act because it seeks to correct abuses that fall outside the scope of traditional antitrust concerns. $^{37}$ In addition the FTCA is viewed as less disruptive of state activities because it, unlike the Sherman Act, cannot be invoked by private parties intent upon recovering treble damages for personal injuries without regard for larger notions of public interest and orderly federal-state relations. ${ }^{38}$ While these distinctions have some force, the fact remains that the FTCA is still, at its core, an antitrust law, ${ }^{30}$ and the effect of preemption upon state economic policy would still be substantially disruptive. ${ }^{40}$ In the final analysis, the question to be answered remains the same: Did Congress intend to preempt state laws either through passage of the Sherman Act or the FTCA? That question can only be answered with confidence in terms of the Parker doctrine.

It should be recalled that Parker held the Sherman Act to be nonpreemptive only if certain conditions surrounding the state regulation were met, such as state-created regulatory machinery operating under the supervision and control of state officials. The Court made clear that

that permissibly interfere with the liberty of contract. See Lochner v. New York, 198 U.S. 45,75 (1905).

35. See STAFP REPORT 493-511.

36. Note, The State Action Exemption and Antitrust Enforcement Under the Federal Trade Commission Act, 89 HARv. L. Rev. 715 (1976).

37. See STAFF REPORT 518-22, citing FTC v. Sperry \& Hutchinson Co., 405 U.S. 233

(1972) (broad interpretation of Commission's "unfairness" jurisdiction).

38. See Note, supra note 36 , at 732-33.

39. See text accompanying notes 53-54 infra.

40. It is true that private parties cannot benefit from its coverage, but the fact is that private treble damages actions may not be a real threat since there is substantial question whether such a remedy is available against a state in the first place. See Edelinan v. Jordan, 415 U.S. 651 (1974); cf. Employees of the Dep’t v. Department of Pub. Health \& Welfare, 411 U.S. 279 (1973) (double damages under FLSA held too harsh for "harmonious federalism"). 
it was interested only in insulating this kind of state action from Sherman Act scrutiny, not in giving all state laws with anticompetitive effect insulation from preemption. ${ }^{41}$ The state must have made a commitment to a regulatory scheme that replaces the market mechanism with some other method of economic regulation. As the Court later held, merely passing a law that abrogates competition is not enough. ${ }^{42}$ In keeping with this approach, a lower court has held that the Parker doctrine does not apply to a section 5 proceeding against a privately controlled regulatory body that restricts competition among its members $^{43}$ and the Commission itself has acknowledged the applicability of Parker to decisions of state milk commissions. ${ }^{44}$ The Goldfarb case serves to confirm the continued vitality of the Parker doctrine, since the Court there made it clear that the Virginia legislature did not fulfill the first Parker condition by involving itself in the regulatory scheme. ${ }^{45}$ Despite the fact that the result in Goldfarb was pro-antitrust, there is little doubt that the Court remams dubious about application of the antitrust laws to state regulated businesses and professions. ${ }^{46}$ Indeed, there are indications in cases like Fry $v$. United States ${ }^{47}$ that the Court

41. Parker contains the following qualifier: "True, a state does not give immunity to those who violate the Sherman Act by authorizing them to violate it, or by declaring that their action is lawful . . . " 317 U.S. at 351.

42. See Schwegmann Bros. v. Calvert Distillers Corp., 341 U.S. 384 (1951) (Louisiana law requiring nonsigners of private agreement to adhere to minimum resale prices set by agreement held state compulsion of private conduct, not Parker-type state action). The McGuire Act, 15 U.S.C. \& 45(a) (1970), which subsequently approved tho conduct forbidden in Schwegmann, was itself recently repealed. Pub. L. No. 94-145, 89 Stat. 801 (Dec. 12, 1975).

43. Asheville Tobacco Bd. of Trade, Inc. v. FTC, 263 F.2d 502 (4th Cir. 1959). The Tobacco Board of Trade, which administered competition by fixing selling time at tobacco auctions, consisted solely of existing members of the industry who used their authority to weaken the marketing position of new entrants.

44. See 32 Fed. Reg. 20,716 (1967) (milk commissions often lave "public" members).

45. 421 U.S. 773. 788-92 (1975). The case might have been different if Virginia had enacted a law requiring minimum fees as an aspect of ethics regulation. The Court went on to hold that even though there was a state regulatory body, the State Bar, with jurisdiction over the ethical conduct of lawyers, that body could not regulate minimum fees as an incident of that jurisdiction. Id. at 791-92.

46. Id. at 792-93. Immediately after deciding Goldfarb, the Court vacated and remanded a decision that held a professional ethical restriction against competitive bidding by engineering services to be a violation of the Sherman Act. See National Soc'y of Professional Eng'rs v. United States, 422 U.S. 1031 (1975).

47. 421 U.S. 542 (1975). Although Fry held that Congress could validly regulate minimum wages and maximum hours of state and local government employees, the Court observed: "While the Tenth Amendment has been characterized as a "truism," . . it is not without significance. The Amendment expressly declares the constitutional policy that Congress may not exercise power in a fashion that impairs the States' integrity or their ability to function effectively in a federal system." Id. at 547 n.7. 
may see fit to revive the tenth amendment as a means of restricting federal regulatory power over affairs traditionally within the state's jurisdiction. ${ }^{48}$

The implications of these developments for the Commission's drug rule should be apparent. As a preliminary matter, it may be that the added search for congressional intent to preempt, suggested by the Parker doctrine, will come into play only when the questioned activity is legislatively enacted and controlled. Thus, if the state law merely proscribed prescription drug price advertising without establishing a pharmacy regulatory board, or some equivalent body, the Parker doctrine arguably would not be applicable. ${ }^{49}$ Alternatively, if the state legislature does not direct the pharmacy board's activities, ${ }^{50}$ or if the legislature has not specifically directed the board to control prescription drug price advertising, ${ }^{51}$ the Parker doctrine would again be displaced. This would suggest that some of the state activities currently sought to be proscribed by the drug rule would not be entitled to the close scrutiny on the preemption issue directed by Parker in any event. In the main, however, the drug rule is seeking to upset enough qualified state schemes to force the rule to be reviewed in terms of the Parker doctrine, to say nothing of imcipient tenth amendment requirements. Therefore, the focus imevitably shifts directly to the issue of congressional authority to preempt state law under the FTCA.

\section{The Search for Congressional Intent}

Before the Commission can preempt state law its power to do so inust be established by Congress. If the implications of Parker are accepted, this grant of power must clearly be found in the legislative history. This search for congressional intent can best be divided into the periods before and after the 1975 amendments to the FTCA, simce those amendments have coincided with, and may in large

48. Subsequent to $F r y$, the Court set down for reargument this term a case seeking further to extend Congress's authority to regulate maximum wages and hours of state employees. National League of Cities v. Dunlop, 421 U.S. 986 (1975). Professor Gunther sees this as an "important straw in the wind" for federalism. G. GuNTHER, Cases and Materials in Constitutional Law 125-26 (9th ed. 1975). Professor Strong is more skeptical. See Strong, Court vs. Constitution: Disparate Distortions of the Indirect Limitations in the American Constitutional Framework, 54 N.C.L. Rev. 125 (1976). If one were to look for exercises of federal power that would be seen to impair a state's integrity or ability to function, attempts to preempt Sunday closing laws would come immediately to mind. See note 34 supra.

49. See note 42 supra and accompanying text.

50. See notes 43-44 supra and accompanying text.

51. See note 45 supra and accompanying text. 
measure have triggered, the Commission's current preemption campaign.

\section{A. Legislative History Before 1975}

A brief review of the legislative history of the 1914 FTCA, which prohibited "unfair methods of competition in commerce," makes clear that the Act itself was seen as a method of strengthening and making more precise existing provisions of the Sherman Act. The concern at the time was with the open-ended nature of the Sherman Act, and the FTCA was initially seen by President Woodrow Wilson as merely creating an advisory arm of the Justice Department that businessmen could turn to for the resolution of antitrust matters. On December 2, 1913, President Wilson addressed Congress on the need to prevent . private monopohes:

I think it will be easily agreed that we should let the Sherman antitrust law stand unaltered, as it is, with its debatable ground about it, but that we should as much as possible reduce the area of that debatable ground by further and more explicit legislation, and should also supplement that great act by legislation which will not only clarify it, but also facilitate its administration and make it fairer to all concerned.

... [T] he business men of this country should be rehieved of all uncertainties of law with regard to their enterprises and investments and a clear path indicated which they can travel without anxiety. ${ }^{52}$

But the 1914 Congress, bolder than Wilson in this regard, adopted a stronger substitute bill ${ }^{53}$ which created a regulatory commission with the authority to promulgate substantive rules of antitrust liability. The phrase "unfair methods of competition" was seen not so much as extending beyond antitrust, but as offering the FTC greater flexibility in regulating monopohistic activities in their formative stages. ${ }^{64}$ Therefore, the 1914 Act principally shored up acknowledged gaps in the

52. E. Brooks, Woodrow Wilson as President 125-26 (1916).

53. Representative Stevens of New Hampshire submitted a substitute bill that had been prepared by Louis Brandeis. See H.R. ReP. No. 533, Pt. 2, 63d Cong., 2d Sess. 4 (1914).

54. See, e.g., 51 CoNo. REc. 14,941 (1914) (Rep. Stevens). There was a lengthy debate, however, over the indefiniteness of the term "unfair competition," with some senators believing it to be limited to the antitrust context and others feeling that it extended beyond traditional coinpetitive injuries. See generally Montague, Unfair Methods of Competition, 25 YALE L.J. 20 (1915). One definitional touchstone the debaters looked to was state law that utilized the term, $i d$. at 36 , indicating an apparent intention not to have the 1914 Act occupy the field of unfair competition regulation. See notes 68 \& 81 infra and accompanying text. 
Sherman Act enforcement powers. In this sense it looked, for preemption purposes, much like the Sherman Act itself.

The subsequent judicial interpretations of the 1914 Act limited it severely by making imjury to competitors a sine qua non to hability. ${ }^{55}$ This led to the 1938 Wheeler-Lea amendments to the FTCA ${ }^{\text {b6 }}$ which gave the Commission jurisdiction over "unfair or deceptive acts or practices" and were designed to biberate enforcement policy by expanding the focus of the original legislation to allow proof of injury to consumers as well as competitors. ${ }^{57}$ While this jurisdiction allowed the Commission to function both as a consumer protection agency and an antitrust agency, there was no indication that Congress intended by that act to allow the Commission to preempt state law. In fact, a search of the 1914 and 1938 legislative history has revealed no discussion of the preemption issue. ${ }^{58}$ In the face of this congressional silence, Parker's counsel seems clearly against preemption. It seems unlikely, therefore, that had the 1943 Parker court been confronted with a challenge under section 5 rather than the Sherman Act, it would have found the requisite congressional intent to preempt. ${ }^{59}$ This certainly does not end the imquiry, however, since there are subsequent legislative developments that remain to be evaluated.

\section{B. The 1975 Legislative History}

Unlike the prior legislation, the 1975 amendment ${ }^{60}$ contains references to preemption in various bills and committee reports that form the legislative background to the final enactment. The 1975 amendment contams two changes which are particularly relevant to an informed discussion of the preemption issue raised by the drug rule. ${ }^{\text {b1 }}$ These are

55. See FTC v. Raladam Co., 283 U.S. 643 (1931).

56. Wheeler-Lea Amendments, 52 Stat. 111 (1938) (codified at 15 U.S.C. $\S$ 45(a)(1) (1970)).

57. See S. REP. No. 221, 75th Cong., 1st Sess. (1937); H.R. REP. No. 1613, 75th Cong., 1st Sess. (1937). Earlier Senator Copeland had observed:

I think it is very.wise that the Federal Trade Commission is going to be permitted to go outside the question of whether or not a given competitor is damaged, because, after all, the person we are thinking most about is not the owner of some commercial concern, but we are thinking about the American citizen. 80 CONG. REC. 6594 (1936).

58. This is the conclusion reached by others as well. See Note, supra note 36 , at $740-41$.

59. Arguably later courts in applying Parker would have reached the same result, but the fact is that the challenge was not presented by the FTC during those years.

60. Magnuson-Moss Warranty-Federal Trade Commission Improvement Act, 88 Stat. 2183 (1975) (codified at 15 U.S.C.A. $\$ \$ 45$ et seq. (Supp. 1976)).

61. The amendment contains two parts: title I, 15 U.S.C.A. \$\$ 2301-2312 (Supp. 1976), which deals with consumer product warranties and title II, 15 U.S.C.A. $\$ \$ 45,49$, 
the rulemaking ${ }^{62}$ and jurisdictional provisions which broaden FTC jurisdiction from matters "in" to those "in or affecting" commerce. ${ }^{88}$ The legislative history behind both of these changes helps to resolve the current imquiry. Of principal concern are the three Senate bills ${ }^{64}$ and one House bill, ${ }^{65}$ each with amendments and accompanying legislative reports, that led to the 1975 amendment.

The first legislative activity occurred in Decennber, 1969, when Senate Bill 3201 was introduced and referred to the Senate Commerce Committee. ${ }^{06}$ After hearings, the bill was reported out of committee in August, 1970, with the following provision:

The amendments made by this title shall not affect the jurisdiction of any court or agency of any State or the application of the law of any State with respect to any matter over which the Federal Trade Commission has jurisdiction by reason of such amendment insofar as such jurisdiction or the application of such law does not conflict with the provisions of the Federal Trade Commission Act, regulations thereunder, or the exercise of any authority by the Commission under such Act. ${ }^{\circ 7}$

This bill, which speaks clearly to preemption for repugnancy, ${ }^{8 B}$ was referred to the Senate Committee on the Judiciary, and was reported out

53, 56, 57 (Supp. 1976), which deals with rulemaking and jurisdiction. The warranty provisions contemplate preemption of state law in certain respects, since the purpose of the provision is to establish uniforn federal rules relating to warranty protection. However, state court jurisdiction and damage liability for warranty disputes is retained, 15 U.S.C. $\S 45$ (1970); 15 U.S.C.A. $\S 2311$ (Supp. 1976), and state laws that afford "greater" protection to consumers and are "effectively" enforced are left undisturbed. 15 U.S.C.A. $\S 2311$ (c)(2) (Supp. 1976). The net effect of the warranty provisions is to postulate a cooperative relationship between state and federal authorities that negates federal intent to occupy the field of regulation so long as states aspire to similar regulatory goals. This is an approach similar to that undertaken by the Commission in its earlier door-to-door sales rule. See note 15 supra. While it is fraught with difficult definitional judgments, the approach appears, in theory, to respect notions of cooperative federalism.

There were other significant FTC "improvements" in the amendment (such as increased fines, inspection of documents, commission representation in court proceedings, and preliminary restraint power) that do not directly raise the preemption issue.

62. 15 U.S.C.A. $\$ 57$ a (Supp. 1976).

63. 15 U.S.C.A. $\S 45$ (Supp. 1976).

64. See notes $66,69,72$ infra and accompanying text.

65. See note 78 infra and accompanying text.

66. S. 3201, 91st Cong., 2d Sess. (Dec. 3, 1969).

67. Id. $\S 106$.

68. The Senate report makes clear that the purpose of section 106 was to indicate that the provisions of the bill relating to expansion of jurisdiction over matters "affecting" commerce "do not preempt or affect state laws not in conflict" with the act. S. Rep. No. 1124, 91st Cong., 2d Sess. 11 (1970). Stated alternatively, this provision was intended to preempt conflicting or repugnant state laws whether the conflict arose 
by that committee on October 5, 1970, without recommendations, but it did not pass the Senate and nothing further was heard from it.

In February, 1971, Senate Bill 986 was introduced. ${ }^{99}$ This bill expanded legislative concern beyond the jurisdictional and rulemaking provisions to imclude the Magnuson-Moss warranty legislation. ${ }^{70}$ While it did not contain a preemption provision as Senate Bill 3201 had done, exphcit reference to preemption by rulemaking is made in the Committee Report:

In the course of the Committee's consideration of the Commission's rulemaking power the issue of preemption was discussed. At the present time a Trade Regulation Rule would preempt state legislation or regulation that conflicted. But the "conflict" test is a very difficult one to apply.

It is the view of this Committee that the Federal Trade Commission would be empowered to prescribe with specificity, when promulgating legislative rules, the extent to which comparable State law is preempted and how it is preempted. For example, if the Commission were to prescribe a uniform national rule governing the practices of door-to-door salesmen it would prescribe the effect of that rule on the various state statutes. It might standardize the forms to be used and the procedures to be followed while specifically leaving state law intact as to enforcement procedures and penalty provisions. ${ }^{71}$

This bill passed the Senate on November 8, 1971, and was sent to the House Committtee on Interstate and Foreign Commerce, but it received no further consideration before the end of the Nimety-Second Congress.

The third Senate bill, Senate Bill $356,{ }^{72}$ was closely patterned after Senate Bill 986 except that it initially contained a section precisely dealing with preemption by rulemaking. ${ }^{73}$ This provision, section 206 ,

directly from the act or the regulations promulgated by rulemaking thereunder. Another reference in the report makes the point that the expansion-of-jurisdiction section "is not intended to replace local enforcement of state or local laws against unfair or deceptive acts or practices." Id. at 9.

69. S. 986, 92d Cong., 1st Sess. (1971). The bill was referred to the Senate Commerce Committee and reported out with an amendment on July 16, 1971. See S. REP. No. 269, 92d Cong., 1st Sess. (1971).

70. S. 986, 92d Cong., 1st Sess., title II (1971).

71. S. Rep. No. 269, 92d Cong., 1st Sess. 28 (1971). It could be argued that the phrase "at the present time" indicated a congressional intent to declare existing FTC jurisdiction preemptive where, for example, it had then been implemented in the door-todoor sales rule. See note 15 supra. But the Ninety-Second Congress's intent with respect to preemption cannot be used retroactively to fill the void created by the silence of earlier Congresses on the preemption issue.

72. S. 356, 93d Cong., 1st Sess. (1973).

73. S. 356, 93d Cong., 1st Sess. \$206(2) (1973) provided:

(vii) Whenever the Colnmission determmes in a rulemaking proceeding 
which appears to be a broad grant to the FTC of preemption power over nonconforming state laws and regulations, ${ }^{74}$ was deleted along with the entire rulemaking section when the bill was reported out of the Commerce Committee. ${ }^{75}$ Significantly, this deletion was requested by Chairman Lewis Engman of the Federal Trade Commission on the ground that then pending litigation would adequately resolve the question of the Commission's rulemaking power. ${ }^{70}$ While the litigation did

\begin{abstract}
pursuant to paragraph $(\mathrm{g})(2)$ that uniformity in the engagement of any act or practice in compliance with a rule issued pursuant to paragraph $(\mathrm{g})(2)$ is in the public interest and necessary to carry out the intent of this Act, the Commission shall include in such rule a description of the extent to which such rule will preeinpt State and local requirements relating to the same acts or practices affected by the Commission's rule: The reasons for preemption, or lack thereof, including the extent of consideration given to the need for uniformity, shall be set forth in the rule with specificity.

Upon petition by any State, or political subdivision thereof, the Commission may, by rule, after notice and opportunity for presentation of views, exempt from the provisions of this subsection, under conditions as it may impose, any State or local requirement that (1) affords protection to consumers greater than provided in the applicable Commission rule, (2) is required by compelling local conditions, and (3) does not unduly burden interstate commerce. The Commission shall maintain continuing jurisdiction over those States or localities specifically exempted under this subsection, and may withdraw the exemption granted whenever it is determined that the State or locality is not efficiently enforcing its requirements or that such exemption is no longer in the public interest.
\end{abstract}

Since this section was subsequently deleted, the Senate Committee report does not discuss its purpose or reach. Its similarity to the approach taken in the consumer warranty legislation should, however, be noted. See note 61 supra.

74. The Committee Report did say, however, that "State and local consumer protection efforts are not to be supplanted" by the affecting commerce jurisdiction. S. ReP. No. 151, 93d Cong., 1st Sess. 27 (1973).

75. The Commerce Committee reported the bill on May 14, 1973, S. Rep. No. 151, 93d Cong., 1st Sess. (1973), and referred it to the Senate Committee on Banking Housing and Urban Affairs (for consideration of provisions relating to unfair and deceptive bank practices) and that committce, in turn, reported the bill out on June 28, 1973. S. RkP. No. 280, 93d Cong., 1st Sess. (1973).

76. The Senate report, S. ReP. No. 151, 93d Cong., 1st Sess. 32 (1973), described the reason for the rulemaking deletion as follows:

During the 92d Congress, the Magnuson-Moss Warranty-FTC bill (S.986) as passed by the Senate contained a provision reaffirming the legislative rulemaking authority of the Commission. A similar. provision was included in S.356 as introduced in the 93d Congress, but in a letter to Chairman Magnuson dated March 26, 1973, Chairman Engman informed the committee that:

. . the commission has concluded that it should await the imminent court decision and seek additional legislative authority only in the event of an adverse decision. The Commission, therefore, recommends that section 206 be deleted from the bill. Such a course will not jeopardize Coin-
mission rulemaking, and, in the meantime, American consumers can begin to reap the benefits associated with prompt enactment of the less controversial amendments provided in the legislation before this committee.

In accordance with the Commission's recommendation, the Committee deleted the rulemaking provisions froin $S .356$ in executive session.

Chairman Magnuson lias pledged, however, to reintroduce legislation granting the Commission the power to promulgate legislative rules in the event of a decision by the courts which is adverse to the Commission on this issue. In other words, the deletion of rulemaking powers by the Committee is not to be read in any way as a reversal of the Senate's position in the $92 \mathrm{~d}$ Congress, 
ultimately decide that the Commission had substantive rulemaking jurisdiction, it did not in any way comment upon the preemption issue. ${ }^{77}$ Senate Bill 356 passed the Senate on September 12, 1973 without a rulemaking provision and was referred to the House.

The House bill that paralleled Senate Bill $356^{78}$ initially contained no reference to rulemaking, but the rulemaking provision as ultimately enacted was added in committee. ${ }^{79}$ The House committee report is silent on specific references to preemption and rulemaking, as are the subsequent conference committee reports of the House and Senate, ${ }^{80}$ but the committee report does discuss preemption in connection with the expansion to "in or affecting commerce." It states:

The amendments made by section 201 will permit more effective regulation of the inarketplace by the FTC by placing within its reach unfair or deceptive acts or practices which, although local in character, affect interstate commerce. The expansion of the FTC's jurisdiction made by this section 201 is not intended to occupy the field or in any way to preempt State or local agencies from carrying out consumer protection or other activities within their jurisdiction which are also within the expanded jurisdiction of the Commission.

Where cases of consumer fraud of a local nature which affect commerce are being effectively dealt with by State or local government agencies, it is the Committee's intent that the Federal Trade Commission should not intrude. ${ }^{81}$

This is the last word on preemption in the legislative history. Senate Bill 356 passed the House and Senate on September 19, 1974, compro-

when it passed legislation by a vote of $72-2$ which expressly conferred legislative rulemaking power upon the Commission.

Chairman Engman was apparently concerned that the pending congressional rulemaking provision might affect the court's judgment about the Commission's substantive tulemaking power under existing legislation, a not uncontroversial issue at the time. See Shapiro, The Choice of Rulemaking or Adjudication in the Development of Administrative Policy, 78 HARV. L. REv. 921, 958-67 (1965).

77. See National Petroleum Refiners Ass'n v. FTC, 482 F.2d 672 (D.C. Cir. 1973), cert. denied, 415 U.S. 951 (1974). At issue were FTC octane rules which did not seek to preempt any state laws or regulations, so the Court had no occasion to deal with the issue of preemption under pre-1975 law.

78. H.R. 7917, 93d Cong., 1st Sess. (1973); see S. 356, 93d Cong., 1st Sess. (1973).

79. See H.R. $7917 \S 202$, 93d Cong., 2d Sess. (1974). For a stateinent of the committee's reasons for adding the rulemaking provision to the bill, see House Comm. on interstate and Foreign COMmerce, Consumer Product Warrantees and Federal Trade Commission Act, H.R. Rep. No. 1107, 93d Cong., 2d Sess. at 3233 (1974).

80. See H.R. REp. No. 1606, 93d Cong., 2d Sess. (1974); S. Rep. No. 1408, 93d Cong., 2d Sess. (1974).

81. H.R. ReP. No. 1107, 93d Cong., 2d Sess. 45 (1974). 
mises were worked out in December, $1974,{ }^{82}$ and the bill became law on January 4, 1975.

\section{AN EVALUATION OF CONGRESSIONAL INTENT}

The foregoing review of the legislative history demonstrates that Congress did not consider the preemptive effect of the FTCA until the events leading to the 1975 amendinent. While it could be argued that congressional silence in the earlier enactments amounts to acceptance of the preemption argument, neither the Commission nor the courts did much to advance that argument in earlier cases $^{83}$ and it remains unconvincing. On this "record" Parker becomes in many ways the closest precedent, and its counsel is against attributing lightly to Congress the intent to preempt in the antitrust field. It is hard not to conclude that something more than silence must be expressed by Congress before Parker-type preemption should take place.

In this respect the legislative history of the 1975 amendment differs significantly from the prior legislative history. Although the version that became law is not as clear on the subject as earlier versions, ${ }^{84}$ Congress clearly worried about the preemptive effect of the rulemaking and jurisdictional provisions of the amendment. In its final expression of that concern, Congress reached what may best be seen as a middle position on the preemption issue that is reminiscent of the approacl taken in the consumer warranty provision. The House report made plaim that the expansion of jurisdiction to "affecting commerce" was not of itself intended to preempt state or local laws or regulations dealing with unfair or deceptive commercial activity. ${ }^{85}$ This establishes that Congress did not, without more, intend for the amendment to occupy the field of consumer protection regulation. But that report goes on to provide, by negative implication, that the FTC may "imtrude" upon state and local enforcement activities when such regulation is ineffective. ${ }^{86}$ The suggestion from this is that repugnancy and even occupation-of-thefield preemption are contemplated when state and local activities are inadequate or counter-productive, which is the case with most of the drug price advertising restrictions. Comcidently, this interpretation reflects a

82. See note 80 supra.

83. There are a few earlier cases that have raised the preemption issue obliquely but they did not discuss Parker and they were decided in a nonrepugnancy context. These cases are collected and well analyzed in Note, supra note 36 , at $717 \mathrm{nn} .13-14$. As the author there concluded, the cases do not present a full consideration of the preemption issue and for that reason are unpersuasive.

84. Compare text at notes 67 \& 73 supra with note 81 supra and accompanying text.

85. See text accompanying note 81 supra.

86. H.R. Rep. No. 1107, 93d Cong., 2d Sess. 45 (1974). 
congressional concern for federalism that is reminiscent of the judicial concern underlying the Parker doctrine.

Moreover, this background to the preemption issue in the jurisdictional context also finds support in the congressional discussion surrounding the rulemaking provision. The report supporting Senate Bill 986 indicates that the rules would preempt state laws and regulations that "conflict" earlier expressed concern that the FTCA not occupy the field of consumer protection regulation. ${ }^{88}$ Congressional intent with respect to repugnancy preemption does not appear to be rebutted by the fact that Senate Bill 356, the bill that became law, had the rulemaking provision temporarily withdrawn from it and ultimately returned in revised form. ${ }^{89}$

The fact that Congress is currently circulating a concurrent resolution which specifically rejects any congressional intent to preempt $^{\mathrm{t0}}$ does not of course affect the basic inquiry of whether preemption was intended in the first place. But the resolution itself seems to be premised on a misapprehension of the important distinction between repugnancy and occupation-of-the-field preemption. The resolution attacks the drug rule for mandating repugnancy preemption in the face of the congressional intent not to preempt state and local regulation that was expressed in the House committee report. ${ }^{91}$ As has been discussed, the focus of that restraint is directed at occupation of the consumer protection field. The report does not appear to restrict Commission activity, taken after careful consideration of the alternatives, that either declares a specific consumer protection law or regulation ineffective (as the consumer warranty legislation does) or declares state laws or regulations outside the consumer protection area imconsistent with the FTCA (as the drug rule does). Whatever its ultimate effect, the concurrent resolution cer-

87. See text accompanying note 71 supra.

88. Under the pre-1975 FTCA, courts have held that the act did not preempt state and local laws and regulations dealing with unfair and deceptive practices. See, e.g.. Patterson Drug Co. v. Kingery, 305 F. Supp. 821, 825 (W.D. Va. 1969).

89. It could be argued that since the Senate report accompanying Senate Bill 356 did not repeat the preemption discussion contained in the Senate Bill 986 report, see text accompanying note 71 supra, preemption was not similarly intended. But given the fact that the provision had been withdrawn at the Commission's request and not at the request of the members of congress antipathetic to preemption, the differences in legislative history do not seem significant.

90. See note 10 supra.

91. H.R. REP. No. 1107, 93d Cong., 2d Sess. (1974). See text accompanying note 81 supra. The concurrent resolution is sponsored by Congressman Staggers (and others); Mr. Staggers also stated the separate views on preemption contained in the house report. H.R. REP. No. 1107. 
tainly encourages the Commission to explore the preemption issue carefully with federalism interests fully in mind.

The review of congressional intent presented here has several consequences for future FTC enforcement actions. If there is no intent to preempt under prior law, the Commission can only proceed against state laws and regulations in terms of the 1975 amendment. And this is not a distimction without a difference. There are, on the contrary, clear limits placed upon the Commission's enforcement alternatives as a result of such a conclusion.

For one thing, the "affecting commerce" provision presumably allows the Commission to broaden its jurisdiction to reach anticompetitive activity in situations where state and local enforcement is "ineffective," but the obligation to make that determination at the outset of an adjudicative or rulemaking proceeding is a real check on the FTC enforcement process. Comphance with it can be measured by the courts, and as the concurrent resolution suggests, monitored by the Congress. Moreover, the 1975 rulemaking provision serves to narrow the Commission's rulemaking power from that which obtained as a result of the National Petroleum Refiners case. ${ }^{92}$ The amendment specifically outlines a rulemaking process that is both procedurally and substantively more stringent than that which obtained under earlier law. The power to preempt state laws and regulations through rulemaking is limited by the additional procedures prescribed in the amendment $t^{93}$ and further limited to rules proscribing unfair or deceptive acts or practices. ${ }^{94}$ The desire to limit the reach of the new rules was apparently the result of a concern by Congress that rulemaking is a powerful tool that should be carefully controlled..$^{95}$ This concern is particularly acute where state laws and regulations are sought to be displaced as ineffec-

92. See note 77 supra. National Petroleum Refiners had held that the Federal Trade Commission Act conferred on the FTC the authority to promulgate trade regulation rules which have the effect of substantive law.

93. See 15 U.S.C.A. \$ 57a (Supp. 1976). It provides procedures for informal rulemaking that exceed the normal notice and comment provisions of the APA, 5 U.S.C. $\S 553(1970)$, including limited rights of cross-examination on issues of fact, the right to oral argument, and the right to a more detailed statement of basis and purpose.

94. See 15 U.S.C.A. $\$ 57 a(a)(2)$ (Supp. 1976). The provision specifically leaves out jurisdiction to make rules with respect to unfair methods of competition, which must now be left to the Commission's rulemaking power under section $6(\mathrm{~g})$ of the FTCA. 38 Stat. 722 (1914).

95. This limitation on the new rulemaking power was discussed in the legislative history by Rep. Broyhill as follows:

Antitrust rules would obviously have a far more pervasive effect than rules de-

fining unfair or deceptive acts or practices, and I would feel very uncomfortable giving such antitrust rules the same effect as this bill gives consumer practice rules. 120 CoNG. REC. 12,348 (daily ed. Dec. 19, 1974). 
tive or counter-productive. Indeed, the rulemaking procedures designate three specific mechanisms to ensure that the preemption decision will be carefully made. First, the additional hearing procedures guarantee that all states will have notice of impending rules and the opportunity to inake a record with oral presentations and cross-examination on specific issues of fact. ${ }^{96}$ Second, the scope of review over the resulting preemptive rule is expanded to ensure that the courts look ciosely at its basis and rationale. And third, the rulenaking provisions specifically allow for exemptions from the rule's effect. ${ }^{97}$ Each of these provisions in its own way serves to implement the felt concern of the 1975 Congress with keeping the preemption function of the FTC under strict control.

\section{Observations on Agency Self Restraint, Federalism AND THE Role OF JUdictal ReVIEW}

An evaluation of legislative history, even that of the 1975 amendment, shows that the ability of the Commission to preenpt state laws and regulations by rulemaking or adjudication is not unconstrained by considerations of federalism. Congressional respect for federalism is reflected in the desire not to intrude upon "effective" state regulation, and in the procedural safeguards surrounding the rulemaking provision. These expressions of concern impose responsibilities upon both the Commission and the courts to determine in each case the appropriate scope of preemption jurisdiction.

The Commission has accepted a restraint upon its enforcement activities that is designed to meet the acknowledged needs of federalstate cooperation. The Staff Report proposes a "standard of selfrestraint" ${ }^{38}$ that establishes the following guideline: "The Commission should only preempt offensive state law that is not (i) vital to achieve (ii) important state policy goals."99 This test bristles with problems of interpretation, but it bears soine reseinblance to the approach taken by the Court in commerce clause litigation. In The Great Atlantic \& Pacific Tea Co. v. Cottrell, ${ }^{106}$ the Court recently overturned a Mississip-

96. The proposed specific issues of fact are required by Commission procedures to be designated by the rulemaking parties in advance of the oral presentations. 16 C.F.R. $\$ 1.16$ (b) (1975). It is frequently not easy to identify such issues in advance, nor indeed on occasion to identify them at all. While the Commission appears to take the position that it is up to the parties to identify these issues, there will undoubtedly be occasions where the record itself will place that burden directly upon the Commission.

97. 15 U.S.C.A. \& $57 \mathrm{a}(\mathrm{g})$ (Supp. 1976).

98. STAFF REPORT 314; see id. at 314-18.

99. Id. at 316.

100. 96 S. Ct. 923 (1976). 
pi state law that forbade the importation of milk from other states unless those states reciprocated by accepting Mississippi milk. The Court overturned this reciprocity clause because it did not reflect a "vital" interest (in public health) which would have been necessary to balance against the "devastating" impact upon interstate commerce. ${ }^{101}$ The Commission's test can borrow this balancing approach in some ineasure, but it should in addition carve out clear limits on the scope of relevant inquiry where possible. For one thing, a solid argument can be unade that the Commission ought never try to displace traditional state public utility regulation that sets minimum and maximum rates, estabhishes terms and conditions of service, and restricts entry and exit. This regulation has historically been free of federal interference even during the substantive due process era $\mathrm{e}^{102}$ and there is little reason to subject it to attack under the FTCA. ${ }^{103}$ Usually this form of regulation surrounds industries which exhibit the characteristics of natural monopolies where coinpetition by hypothesis cannot exist. In some cases, such as milk regulation, ${ }^{104}$ the natural monopoly analogy is inapposite even though the state regulatory sclieme is of the public utility type. From a preemption perspective, this economic distinction should be irrelevant. The question is not whether the state chose properly by perceived economic rationales to displace the private market, but rather, whatever the source of its choice, whether the regulation is necessary to accomplish important state policy goals. The focus is on the nature and thor-

101. The Court concluded:

Only state interests of substantial importance can save [the reciprocity clause] in the face of that devastating effect upon the free flow of interstate milk.

Mississippi's contention that the reciprocity clause serves its vital interests in maintaining the State's health standards borders on the frivolous. Id. at 930.

Cf. Struve, The Less-Restrictive-Alternative Principle and Economic Due Process, 80 HARV. L. REV. 1463 (1967).

102. See Verkuil, supra note 12 , at $330-40$.

103. The recent concern with anticompetitive state-inspired protections of the professions does not appear to have undermined traditional state economic regulation. Goldfarb, for example, sustained an attack upon minimim fee schedules which, even if state regulated, were not designed to regulate competition in the public interest as maximum rate regulation is, in theory at least. And the theory of the regulation is as far as the Commission ought to look. To go beyond the regulatory theory would entangle the Commission in imponderable questions about the quality of the regulatory performance and lead it to second guess individual ratemaking determinations.

104. The Commission has recently attacked by adjudication advertising practices of the California milk regulatory authority that were approved by the State's Director of Food and Agriculture. Its action was enjoined on the basis of Parker. California ex rel. Christensen v. FTC, 1974-2 Trade Cas. If 75,238, at 98,038 (N.D. Cal. 1974). An appeal to the Ninth Circuit is pending. The Commission had earlier issued an advisory opinion that acknowledged the relevance of Parker to decisions of state milk commissions. See 32 Fed. Reg. 20,716 (Dec. 21, 1967). 
oughness of the regulatory scheme, not the commitment to microeconomic theory. For the FTC to require more would be tantamount to a return to the substantive due process era that neither Congress nor the Constitution ${ }^{105}$ is prepared to accept in the economic realm. ${ }^{108}$ Therefore, so long as the form of regulation is of the public utility type, it can be viewed as per se "vital" and Commission preemption jurisdiction should be restrained.

Beyond the public utility context there are other state laws that are also "vital" for other reasons. Sunday closing laws and other blue laws have developed over time as reflections of rehgious and community customs. ${ }^{107}$ They reflect notions of state sovereignty that in some cases antedate the Constitution itself. ${ }^{108}$ While these laws may violate principles of economic efficiency, they are nonetheless basic to the fabric of our society and any atteinpt to upset them would pose a serious challenge to federalism.

In other areas, the question of what laws and regulations are vital to important policies inust be decided on a case-by-case basis. There may be some situations, within the category of professional hicensing, for exainple, where state policy will becoune important upon closer study. In these cases rulemaking is the ideal decisionmaking framework: it maximizes the scope of analysis prior to decision, and for this reason is broadly acknowledged to be the superior forum to raise and resolve policy disputes. ${ }^{109}$ In the drug rule, for example, every state has been given an opportunity to make arguments on why the ban on advertising of drug prices is vital to important policy goals. The Commission has stated the evidentiary burden as follows:

As to drug price disclosures, if net consumer injury is large enough and federal public policy favoring price disclosure and price competition clear enough, then state anti-advertising laws inust be essentially indispensible to achieve critical state policy goals if they are to be spared preemption. ${ }^{110}$

In addition the Commission has itself collected and analyzed several of the most familiar arguments in favor of advertising restrictions as a

105. Cf. Tribe, Forward: Toward a Model of Roles in the Due Process of Life and Law, 87 HARV. L. Rev. 1 (1973).

106. It is in this way that the commerce clause preemption analysis offered in Cottrell departs from the FTCA preemption analysis proposed herein.

107. See, e.g., Sherbert v. Verner, 374 U.S. 398 (1963); McGowan v. Maryland, 366 U.S. 420 (1961).

108. See note 34 supra.

109. See K. Davis, Administrative Law Text $\$ 6.03$ (3d ed. 1972).

110. StAFF RePort 317. 
means of focusing the discussion. ${ }^{111}$ If there are important arguments to be made by the states in opposition to the drug rule, every opportunity permits them to be made. Indeed in some ways states get a inuch better hearing on the preemption issue before the FTC than they would before a congressional committee that was proposing a federal law which would have a similar preemptive effect. While a state loses the right to have its representatives vote directly on the proposition, it nonetheless gets a full blown examination of the issue before an mdependent and expert body with time to assess, reflect and reply in an orderly fashion that is rarely available in Congress.

The role of the courts in judicial review of rules that preempt state laws or regulations is a crucial aspect of the continued protection of federalism conteinplated by the 1975 amendment. While courts usually exercise soft review of federal laws that happen to have preemptive effect, ${ }^{112}$ the rulemaking provisions grant the courts a more active role in determining whether the FTC has by rule undermined state policies. The more tough-ininded standard of substantial evidence review is the device einployed. ${ }^{113}$ In effect the courts on direct review of the rules must make two determinations: whether the rule is justified in terms of the facts in the rulemaking record, and whether it is the kind of rule the Commission has the jurisdiction to make preemptive. In deciding the second question, the courts have the assignment of second guessing the Commission on whether vital state laws and important state policies have been overridden. This scrutiny is somewhat different from the scope of review over facts that is normally associated with the substantial evidence test. ${ }^{114}$ But the challenge is no less direct. The court is encouraged to consider closely the rationality of the rule in terms of the appropriateness of preemption. This requires much the same kind of examination as does a review of the jurisdictional facts upon which an agency decision is based. The record of the drug rule, for example, will

111. Alleged disadvantages of price disclosure discuissed by the Commission include drug abuse problems; interference with patient drug use; demeaning of the pharmacy profession, and so forth. See STAFF REPORT 289-473.

112. See, e.g., North Dakota Bd. of Pharmacies v. Snyder's Drug Store, 414 U.S. 156 (1973); Ferguson v. Skrupa, 372 U.S. 726 (1963) (upholding state statutes).

113. This standard, 15 U.S.C.A. \$ 57a(e)(3)(A) (Supp. 1976), provides for rules to be set aside if "the court finds that the Commission's action is not supported by substantial evidence in the rulemaking record . . . taken as a whole . . . " Rulemaking record is defined as the rule, the statement of basis and purpose, the transcript, any written submissions and any observations considered relevant by the Commission. Id. \& $57 \mathrm{a}(\mathrm{e})(1)(B)$. This definition assists the court in knowing the limits of its reviewing role. See Verkuil, Judicial Review of Informal Rulemaking, 60 VA. L. REv. 185 (1974).

114. See generally Universal Camera Corp. v. NLRB, 340 U.S. 474 (1951). 
show whether the states have demonstrated vital interests that ought to preclude preemption. Indications that some states favor the rule while others do not cut against a conclusion of uniform importance of the state policy. Indeed, where it can be shown that the states divide on the preemption issue, the case for overturning the rule is weakened. One of the advantages of the rulemaking context is that, by virtue of the exemption provision, ${ }^{115}$ a national rule can be established without necessarily ignoring the exceptional situations of a few isolated states; these can be dealt with individually (and by the same standard) at a later time.

\section{Concluston}

The sensitive issue of the FTC preemption of state laws and regulations that inhibit competition is best resolved by the cautious analysis expressed in Parker v. Brown. ${ }^{116}$ This requires a close look at congressional intent to determine whether the power to preempt has been granted to the Commission. Indications are that before 1975 such intent was lacking. In 1975, however, Congress passed an amendment that reassessed the preemption issue in light of perceived notions of federalism. While the Commission was not given the authority broadly to occupy the field of state unfair competition in consumer protection law, it was authorized to declare by rule preemption of state activities that conflict with federal regulations. Since the rulemaking provisions are carefully surrounded by procedural protections, minimal injury is done to federal-state relations. In the drug rule this new approach is being implemented for the first time, and indications are that federalism interests can be protected while some measure of competition is simultaneously restored to the prescription drug market. It remains to be seen whether the course of the Commission's preemption rulemaking will be comparably charted in the future.

115. 15 U.S.C.A. \& 57a(g) (Supp. 1976).

116. 317 U.S. 341 (1943). Professor Handler has recently emphasized the need to consider Parker as "integral to our federalisin" in order to resist the increasingly popular notion of broad Sherman Act preemption of state laws and regulations. See Handler, supra note 12, at 20 . This message helps fix a proper scope for preemption under the 1975 FTCA amendments as well. 
. 